\title{
Grupos de trabalho: avaliação e proposta
}

$\mathrm{Na}$ assembléia geral da $14^{\mathrm{a}}$ Reunião Anual da ANPEd, em São Paulo, foi aprovada a "Proposta da Diretoria sobre a Nova Concepção da Reunião Anual e Funcionamento dos GT". Em 27 de novembro de 1991, a Presidência da ANPEd designou os ex-presidentes da Associação para, em comissão, avaliar a trajetória e a estrutura dos GTs e encaminhar proposta sobre criação e funcionamento dos mesmos, para a próxima reunião anual.

A comissão composta por Jacques da Rocha Veloso ( $1^{\circ}$ presidente), Maria Julieta Costa Calazans ( $2^{\mathrm{a}}$ presidente), Glaura Vasquez de Miranda ( $3^{\mathrm{a}}$ presidente) e Osmar Fávero ( $4^{\circ}$ presidente) reuniu-se na FAE/UFMG, em Belo Horizonte (CMG), nos dias 28 e 29 de maio de 1992. Miguel Gonsales Arroyo (vicepresidente da Diretoria na ocasião) assessorou a comissão, relatando suas conclusões.

Após avaliar o funcionamento dos GTs, a comissão elaborou proposta relativa aos seguintes aspectos: 1. Funções dos GTs; 2. Critérios para criação dos GTs; 3. Critérios para funcionamento dos GTs; 4. seleção de trabalhos, publicações, intercâmbios e relação com comitê científico; 5. Sugestões para fi- nanciamento; 6. Eleição dos coordenadores, suas tarefas, relações inter-grupos e com a Diretoria da ANPEd.

O documento "Grupos de Trabalho da ANPEd: avaliação e proposta" foi encaminhando à Presidência da ANPEd, com vistas a sua apresentação e discussão na $15^{\text {a }}$ Reunião Anual, tendo sido aprovado na Assembléia Geral.

\section{Funções dos GTs}

1.1. Reunir pesquisadores, estudiosos e interessados em trabalhar determinada temática e/ou área da prática educacional.

1.2. Construir-se em espaço de conforto intelectual sobre propostas teórico-metodológicas diferentes e em espaço de produção científica como grupo ou por seus membros individualmente.

1.3. Acompanhar e analisar a produção científica produzida na temática e/ou área e provocar produção nova, principalmente nas linhas "de ponta" ou "de fronteira".

1.4. Articular e acompanhar projetos integrados 
de pesquisa, discutir seus resultados, questionar seus objetivos, teorias e métodos.

1.5. Influir na melhoria das disciplinas e enriquecer os projetos de pesquisa dos Programas de PósGraduação em Educação, quanto aos conteúdos, objetos de investigação, teoria e método.

1.6. Acompanhar a produção teórica sobre sua temática nas áreas afins, em plano nacional e internacional, estando especialmente atento à reflexão e à realidade latino-americanas, visando ampliar os horizontes da reflexão e das pesquisas.

1.7. Produzir bibliografias analíticas selecionadas e/ou estados do conhecimento sobre os temas específicos a que o GT se dedica, em especial identificando, processando e analisando a produção nacional e internacional recente, detectando vazios, tendências, perspectivas, quanto aos objetivos, teorias e métodos.

1.8. Organizar e/ou promover reuniões de intercâmbio entre pesquisadores, na forma de estágios, seminários, worshops e reuniões de produção científica e preparação de publicações sobre sua temática e/ou área.

1.9. Realizar e/ou promover análises de conjuntura e elaborar estudos e pareceres sobre temas de sua especificidade.

\section{Critérios para criação dos G Ts}

2.1. Apresentar à assembléia geral da ANPEd, através da Diretoria, proposta de trabalho fundamentada, que não se superponha aos grupos existentes, para um período experimental de dois anos, encaminhado por um mínimo de dez pesquisadores, doutores e/ou mestres representativos do Programas de PósGraduação em Educação de regiões diferentes.

2.2. Indicar um coordenador que se responsabilize pelo funcionamento do GT no período experimental, com o apoio do Programa de Pós-Graduação em Educação a que estiver vinculado.

\section{Critérios para funcionamento dos GTs}

3.1. Núcleo mínimo de dez pesquisadores, re- presentativos de Programas, situados em regiões geográficas diferentes, com uma coordenação efetiva.

3.2. Plano de trabalho para cada dois anos, avaliado e detalhado ano a ano, por ocasião das reuniões anuais da ANPEd.

3.3. Produção significativa em termos de:

a) participação nas reuniões anuais, com trabalhos de bom nível;

b) participação nas reuniões amplas da área (Conferência Brasileira de Educação, seminários etc.) e sociedades científicas (SBPC, ANPOCS, ANPHU etc.);

c) elaboração e coordenação de projetos integrados de pesquisa;

d) edição de bibliografias e publicações de artigos e livros decorrentes de sua produção

e) organização das reuniões de intercâmbio, estágios etc.

3.4. O GT que não puder apresentar trabalhos de bom nível durante uma reunião anual, ou após dois anos de funcionamento, poderá vir a dispor de mais um ano para sua reestruturação ou consolidação, a critério da Diretoria, ouvido o comitê científico.

3.5. O GT que não apresentar trabalhos de bom nível em duas reuniões anuais sucessivas ou não conseguir reestruturar-se ou consolidar-se após o ano de prorrogação concedido evidencia a necessidade de buscar novos caminhos, e suas atividades poderão ser extintas ou suspensas temporariamente por decisão da assembléia geral, a pedido de seus membros ou por proposta da Diretoria da ANPEd.

\section{Eleição do coordenador, suas tarefas, relações intergrupos e com a Diretoria}

6.1. O coordenador será eleito pelos membros do GT por um período de dois anos e reconduzido no máximo por mais dois.

6.2. Caberá aos coordenadores:

a) programar as reuniões do GT, intercâmbios, estágios e propor a participação do GT em reuniões mais amplas (CBE, SBPC...); 
b) responsabilizar-se pela circulação das informações entre os membros do GT;

c) programar as interfaces e/ou trabalhos conjuntos com outros grupos;

d) programar, com a Diretoria, os convites e financiamento da participação nas reuniões anuais em seminários, estágios etc.;

e) garantir a renovação dos elementos do GT.

6.3. Para realizar essas tarefas, o coordenador deverá contar com o apoio do Programa de Pós-Graduação em Educação a que estiver vinculado.

6.4. A Diretoria da ANPEd procurará apoiá-lo administrativa e financeiramente na realização dessas tarefas.

Transcrito de Boletim ANPEd, v. 14, n² 2, out.-dez, 1992. 15 Reunião Anual, Caxambu, 13 a 17 de setembro de 1992. Relatório, p. 92-97, exceto itens 4 e 5 , que sofreram alterações significativas nos últimos anos.

Observa-se que as normas para criação e funcionamento dos GTs, em particular sua articulação na montagem das reuniões anuais, foram objeto de discussão em praticamente todas as reuniões anuais da ANPEd, como pode ser visto nos relatórios disponíveis. 